\title{
TTR
}

Traduction, terminologie, re?daction

\section{Kafka Across the Intertexts: On Authority in Translation}

\section{Patrick O’Neill}

Volume 5, numéro 2, 2e semestre 1992

Kafka pluriel : réécriture et traduction

URI : https://id.erudit.org/iderudit/037122ar

DOI : https://doi.org/10.7202/037122ar

Aller au sommaire du numéro

Éditeur(s)

Association canadienne de traductologie

ISSN

0835-8443 (imprimé)

1708-2188 (numérique)

Découvrir la revue

Citer cet article

O'Neill, P. (1992). Kafka Across the Intertexts: On Authority in Translation. TTR, 5(2), 19-40. https://doi.org/10.7202/037122ar d'utilisation que vous pouvez consulter en ligne.

https://apropos.erudit.org/fr/usagers/politique-dutilisation/ 


\section{Kafka Across the Intertexts: On Authority in Translation}

\section{Patrick O'Neill}

"Someone must have traduced Joseph K., for without having done anything wrong he was arrested one fine morning," Willa and Edwin Muir felicitously open their 1937 translation of Franz Kafka's novel The Trial, though in later editions the expression "traduced" is replaced by the more quotidian "been telling lies about" $(1970, p$. 1). The present paper is concerned with the traducing not of Joseph $\mathrm{K}$. but of Franz Kafka - with the translation of Kafka, that is to say, for while one now obsolete meaning of the verb "to traduce" is indeed "to translate," its only current meaning is precisely "to tell lies about," and in one sense translation is always a calculated process of telling lies about its object of interest. ${ }^{2}$ Kafka, after all, clearly wanted his text to read neither "Someone must have traduced Joseph K." nor "Someone must

1. Earlier versions of this paper were delivered to audiences at McMaster University, the University of Toronto, Queen's University, Laurentian University, the University of Victoria, the University of British Columbia, and the University of Manitoba. My thanks are due to all of these groups for valuable feedback, as also to the participants in a Comparative Literature seminar at the University of British Columbia, where the paper had its origin; to Barbara Sinnemann, whose MA thesis on English translations of Das Urteil was written at Queen's University under my direction; and to Roberta Ascarelli of the University of Toronto, who kindly provided me with Italian translations of Das Urteil. 
have been telling lies about Joseph K." but rather "Jemand musste Josef K. verleumdet haben" (Der Prozess, 1964, p. 7). What is perhaps not so clear is who (or what) this "Kafka" I can talk about so glibly here was (or is). For most of us, most of the time, certainly, it is merely a commonplace and completely untroubling metonymy to say that we are reading "Kafka" or "Dostoevsky" or "Molière" when what we are really reading is the body of work produced by them. Nor, usually, is the metonymy any more troubling if the texts we are actually reading happen to be in translation rather than the original, and few of us would consider we were being anything less than totally truthful in claiming to have read, say, the Bible, even if we were completely ignorant of either Hebrew or Greek. Likewise, as good academics, we have all certainly read Homer and Virgil, Dante and Goethe, Cervantes and Shakespeare, Tolstoy and Proust. Or have we? Are we really being as entirely truthful as we may very well think we are?

The notion that translation is always more or less a tissue of lies on a more obvious level is, of course, an easy commonplace, a popular wisdom. "Traduttore, traditore," as the Italian aphorism has it, 'Translator, traitor.' These traitorous translations in turn, as the matching French aphorism, with cheerful sexism, puts it, are like "les belles infideles" - the more beautiful they are, the less likely they are to be faithful. ${ }^{2}$ And the contemporary analogue of this wisdom is that the movie, as we all know, is never as good as the book. Exceptions merely prove the general, if more or less unquestioned rule. But what does "as good as" mean? What constitutes treason? How do we measure fidelity? What, in other words, are the concepts of textual authority that underwrite, inter alia, our notions of evaluation as far as translation is concerned?

Traditionally, translation has been imbued with and surrounded by what one might call a quasi-religious myth of originality. We see this at work, for example, in a statement such as Horst Frenz's that "in general, translations date more quickly than their original" $(1961,1973$, p. 119). Why, we might well ask ourselves, should this be so? Pope's translation of Homer, for example, began to appear in 1715 , just a year

2. For a collection of such aphorisms, see Koller (1984), pp. 48-51. 
after the appearance of one of his "own" works, The Rape of the Lock. Have these two texts really aged over the intervening centuries at differential rates? And if so, why? And what does "in general" mean? Perhaps it refers to that other common manifestation of the myth of originality, the casual and widespread assumption that translations by "real authors already" are somehow superior, better, more the "real thing" than translations by individuals who are not real authors but merely members of that presumably inferior literary breed, translators, who by definition are incapable of producing the real thing - unless, of course, like Pope, they write a book of their "own," an original text, which then, by definition, will at least have some defensible claim to being considered the "real thing." And again, what of "translations" that turn out not to have been translations after all? James Macpherson's alleged translations in the 1760 s from the Gaelic of Ossian, for example, eventually turned out to be simple forgeries. But simple forgeries in this case meant Macpherson's own original work. Does he (or should he), any moral considerations aside, consequently occupy a rightfully higher rank in literary history precisely because he was a literary swindler? Where, in other words, is the "real thing" here? Is there, indeed, any such thing, here or elsewhere, as the real thing?

The myth of originality reveals itself most obviously in the master/servant relationship that has traditionally obtained between socalled original texts and their translations - or, more accurately, between original authors and their translators. In this relationship the translator's task was to become as transparent, as inconspicuous, in a word, as absent as possible in order that the creative originality of the author might shine through unimpeded and unimpaired. This model of translation, moreover, was only one aspect of a larger model of reading in general, for even the original author's work was itself to some degree already a translation, since literary works are constructed out of language, and the task of language in this relationship was likewise to become as transparent and inconspicuous and essentially absent as possible in order that the real meaning of the author might shine through without distortion or distraction. The formula governing the relationship of original and translation was thus as follows: the original author is to the transparent translator as original meaning is to 
transparent language. Or as master is to servant, for in this scheme of things translation serves "literature," which in turn serves truth. ${ }^{3}$

So whom are you reading when you read, say, Kafka in translation? Under the traditional dispensation, as outlined here, the answer could only be that one read as if reading Kafka: on the one hand what one read was really Kafka, but on the other hand it was not really Kafka, but Kafka through a glass, a more or less dirty glass, darkly. The translator, essentially an imposter, was essentially also more or less of a nuisance - and ideally less, of course, for the ideal translator in this scheme of things is entirely invisible, writes himself (like the Cheshire Cat) entirely out of existence, out of the text.

Thus what we may call the traditional model of translation, based on the twin pillars of authorial originality and authorial authority - and deriving ultimately from the essentially religious concept, at once theocentric and theocratic, of a divine revelation. In the aftermath of structuralism and its assorted developments, however, there has been a paradigm shift in the late-twentieth-century concept of the role of the translator, just as there has been in the case of the literary critic. The new paradigm is based less on the mysteries of divine revelation than on the semiotics of literary communication and owes less to the radically centralized power structure of pre-industrial political and religious autocracy than to the decentralized structures of information management in our (post)modern, (post)democratic, (post)industrial Western societies. My aim here is not to attempt any would-be comprehensive outline of contemporary translation theories, ${ }^{4}$ but it can none the less be confidently asserted that one crucial common factor is the notion of textuality, more specifically the notion that all translations are first and foremost metatexts - that is to say, linguistic texts about other linguistic texts. This metatextual model of translation practice sees

3. Terry Eagleton (1983, esp. pp. 1-16) draws attention in exemplary fashion to the parallel relationship traditionally held to obtain between theory, criticism, and literature: the task of literary theory is to serve literary criticism, whose task in turn is to serve literature.

4. For such surveys, see Bassnett-McGuire (1980), Koller (1984); see also Lefevere (1982). 
all translation as essentially compound discourse, discourse about other discourse, and as a result the authority that was formerly seen as residing solely and unshakeably with the historical, empirical author and his inalienable claim to originality is now seen as displaceable throughout an entire textual system, which includes not only the author and his text but also a potentially infinite series of translators, who may subsequently, as new "authors," create their "own" texts based to a greater or lesser degree on their encounter with this one, originary text. Each of the new "Kafkas" produced under this new theoretical dispensation has a more or less defensible claim to being the "real" Kafka, for that reality is now grounded in textual rather than biographical authority, whether or not the text under analysis is the only true original or a displaced variant of it.

Again, this new model of translation is also only one aspect of a more general model of reading - whose broader resonances may also be observed in areas of critical practice not owing any direct allegiance to structuralist ideas in the narrower sense, such as the New Critical theory of the autotelic text. In the metatextual model of compound discourse author A produces text B which is read by reader C. But readers are of very different kinds, and their processing of the textual information is infinitely variable. Indeed, in this scheme of things no reader can ever read the same text twice, for as individuals we are subject throughout our existence to ineluctable change, and the texts we read duly change with us. Some readers, moreover, are more productive than other readers, and while every reader potentially produces his or her own text in processing the text of author A, some readers go on to actually write down their own texts, in which case one of the labels we can give to such readers is that of translator. Every translator is both a reader and an author, in other words, and every translator of Kafka, for example, constructs in the required target language, as author, an analogue to the Kafka he has reconstructed as a reader in the source language of the text. But this is essentially true of any reader, for all our readings are always simultaneously reconstructions and reconstructions, decodings and encodings, taking apart and putting together again a text that is simultaneously the same and uniquely different. A translator, in short, under the new theoretical dispensation, is nothing more or less than a fully consistent reader, a reader with the courage of his or her convictions. Every translation of Kafka is a new 
reading of Kafka, and every reading is at least potentially a new translation.

So, once again, who (and where) is Kafka? For the traditional model of the older paradigm, as we have seen, Kafka is a unique historical individual of genius, born in Prague in 1883, the unique locus of the text's authority (whether in translation or not), the ultimate origin of all its meaning - and essentially the same for every reader. For the metatextual model of the new paradigm, on the other hand, authority is displaced from the original author to the interaction of individual texts and individual readers, and "Kafka" is the Kafka constructed by each individual reader in a proliferating string of readings (whether in translation or not). But it is also possible, still operating by the game rules of the new paradigm, to theorize a third - if entirely "impractical" - answer to the question, which we may call the intertextual model (and on whose hypothetical workings we shall now concentrate): for this model, Kafka is neither a unique and unchanging individual nor a proliferation of endlessly variable individual readings but rather an entire shifting system of potentially endless variable readings, the sum, that is to say, of all the translations and readings of Kafka that have ever existed or will ever exist in any language. If the locus of textual authority was firmly identified with the historical, empirical author in our first model (which is prestructuralist in its assumptions), and displaced on to individual textual encounters in the second (essentially structuralist in its assumptions), in the third, which is poststructuralist in its general assumptions, the locus of authority is dispersed, disseminated, diffused throughout the entire textual system.

This translation of authority is, once again, by no means limited to translated texts, for all three of these models are models of reading in general rather than just of reading translations. Texts in translation, however, provide a particularly graphic set of examples of the issues involved. Authority is essentially extratextual in the first model, the traditional reader reading through the words on the page (whether translated or not) to the living thoughts and intentions of the unique and uniquely authoritative historical author. In the second model authority is essentially metatextual in that it begins with the concrete text on the page, sometimes actually and always potentially translated by the further textualizing process of its reception by successive readers. 
In the third model authority is essentially intertextual, for this model, subscribing to poststructuralist notions of textual interaction, duly holds that a Kafka read in Spanish cannot be the "same" Kafka read in French or English or German, that your Kafka is not my Kafka, and that my Kafka today is not my Kafka of yesterday or tomorrow - and yet all of these synecdochic Kafkas together comprise the macrotext we also call "Kafka," the Kafka phenomenon, the Kafka system. Where the traditional model is unitary (one Kafka for all readings), and the matatextual model is pluralist (one Kafka for each reading), the intertextual model is theoretically holistic (since all possible readings constitute one Kafka). The sum of this intertextual system, of course, must always remain incalculable, and its "one" Kafka infinitely ungraspable, not merely because of the linguistic and other limitations of individual readers, but because any attempt to sum the system would inevitably be an exercise in paradox, since the macro-Kafka it produced would then have to be included in a new mapping, and so on in endless circular regression.

The impossibility of the endeavour as a whole need not deter us from exploring the beginnings of one or two of its proliferating pathways, however, and we shall now turn our attention to this experiment. To this end the reader will find an appendix to this paper containing the opening and closing sentences of Kafka's story Das Urteil - in the original German, three different English translations, two French versions, two Italian versions, and one Spanish rendering. Ideally the selection should, of course, be very much larger, but it will suffice to demonstrate the general principle of the intertextual model.

The story of Das Urteil, to establish the context, is quickly summarized: Georg Bendemann, a young businessman, writes to a bachelor friend in Russia to announce his recent engagement and shortly thereafter informs his elderly father that he has just written the letter. Whereupon his father accuses him (a) of having invented the friend and (b) of having disgraced his dead mother's memory by the planned marriage. Moreover, (c) the friend, non-existent or not, is really his friend; (d) the girl would be his too, if he wished; and (e) since Georg had always wished his father dead, now he sentences Georg himself to death, by drowning. Georg rushes from the house and throws himself 
off a bridge. ${ }^{5}$ Let us now proceed to look at some selected phrases in all nine of the versions before us - but with the specific understanding that we are not going to treat one as the original and the other eight as more or less unsuccessful renderings, but rather (and this is the point of our experiment) that we shall treat all nine as a single multivoiced, translingual "original," an interweaving and interwovenness of voices in which the individual voices will sometimes agree and sometimes differ - but each voice will always relativize each of the others and, in so doing, put itself continually in question as well. We can, to begin with, let Kafka's German be our point of departure, a privileged voice, but this is a matter merely of convenience rather than necessity, since we could just as easily declare the Spanish version to be our privileged voice and the German version to be just one more of the many other competing voices. Ideally, no single one of the individual voices would be privileged for the purposes of this exercise, the multipart harmony of these textual spheres emerging precisely from the interplay of all the voices simultaneously, with now one and now another of them seizing our attention by virtue of a particularly brilliantly or strikingly executed effect. $^{6}$ (In order to suggest something of the nature of this interplay I will refer to the versions only by the letter and number identifying them in the appendix, rather than by the name of their individual author.)

"Es war an einem Sonntagvormittag im schönsten Frühjahr," begins the German A1. We notice that while the German superlative "im schönsten Frühjahr" ostensibly draws attention to the beauty of this time of year, only two of the other voices do so, the French A5 referring to "la beaute du printemps" and the Italian A8 to the

5. The reader need hardly be wamed as to the highly dubious status of such neatly phrased summaries. This, after all, is only one of many such summaries I could have provided, and I am only one reader among many.

6. It should not be forgotten, of course, that I find particular effects striking in the first place because of my own overall reading of Das Urteil. Another reader might well ignore the effects I find most striking and focus instead on shadings that I ignore or have simply not been able to see. 
"momento più bello della primavera." The English voices all prefer to employ a metaphor of height instead - "in the (very) height of spring" - a metaphor that will become startlingly concrete in the climactic scene of the narrative, when Georg's father springs to his feet on the bed, even touching the ceiling with one hand to steady himself, as he pronounces judgement from on high. The Spanish A9 employs a metaphor of fullness instead - "en plena primavera" - while the French A6 ironically speaks of "une année qui débutait splendidement," echoed by the Italian A7, "faceva un tempo splendido." "Georg," as he is called in German and Spanish and by two of the English voices, metamorphoses into "George" in A4, "Georges" in both French voices, and "Giorgio" for both Italian voices, a cultural change of key interestingly paralleling the polarity of familiarity and strangeness informing the relationship of Georg (as we may continue to call him) and his nameless friend in a stylized Russia. Georg is "ein junger Kaufmann" in A1, a "merchant" in A2, a "businessman" in A3 and A4, a "commerciante" in A7 and A8, a "comerciante" in A9. For both of the French voices, however, he is "un jeune négociant," and this catches with absolute precision the element of competition and rivalry that will emerge as existing between Georg and his Russian friend on the one hand, Georg anc his father on the other. A "négociant" is one who negotiates, employs strategies, devises game-plans, in order to gain a superior position, and the course of the struggle between Georg and his father that will come to dominate the story can be traced in detail as constituting a series of such antagonistic game situations. (If I might interrupt the rules of my own game momentarily and interject a comment of an evaluative nature at this point, by the way, here is one example of a translation that is clearly superior to the original - but only, of course, for the purposes of this particular interpretive angle.)

Georg's friend in Russia is described in German as being "im Ausland," which on the one hand simply means "abroad," as all three English versions neutrally phrase it, but also, and far less neutrally, "l'étranger" of both French voices, the "estero" of both Italian voices, 
and "el extranjero" of the Spanish." Georg "hatte gerade einen Brief an [diesen] sich im Ausland befindenden Jugendfreund beendet [und] verschloss ihn in spielerischer Langsamkeit," according to Al. We notice in passing the polarity of youth and age between the "Jugendfreund" of the German and the "old friend" of two of the English voices. We notice too that while for all the English and French and one of the Italian voices the friend was quite neutrally "living" abroad - "résidant" (A5), "habitait" (A6), "viveva" (A8) - in German he is "sich im Ausland befindend," and for the Spanish (echoed less forcefully in the Italian A7) the friend likewise "se encontraba en el extranjero," which taken completely literally means "he met himself (or found himself) in that which was strange."8 Would Georg too "find" himself, "meet" himself as if he were a stranger, if he too had the courage or the resolve or whatever it took to risk leaving the security of the known and the familiar for the unknown and the strange? There are (at least) two sides to everything, of course - including writing a letter, which for A1 Georg had just "beendet." For two of the English voices (A2, A3) he had just "finished" this letter, just as for both Italian voices he "aveva finito," or in other words had simply ceased to write any more, while for the third English voice he had "completed" it, or in other words had brought it to a successful conclusion. The same tension is exactly reflected in the two French voices: A6 prefers "terminer," simply to reach an end, while A5 prefers the more active "achever," to achieve or bring about an end, a choice also favoured by the Spanish, where Georg "acababa de escribir," which taken quite rigorously at its word - like the French "achever" - means that he had brought his writing to a head. We notice, incidentally, that the Spanish is the only voice that actually mentions "escribir" 'writing' at this point - all the other voices, including the German, simply refer to

7. It should, of course, also not be forgotten that I have no choice but to read all of the texts as a reader whose first language is and remains English. My ear for nuance and "neutrality" will therefore clearly be quite different from that of a non-English speaker. This, however, is entirely in accordance with the assumptions of our third model.

8. The innocence of the "literal" translation here is, of course, also entirely questionable. 
the finishing or completion of "a letter," "einen Brief," "une lettre," "una lettera," "una carta."

This letter Georg had put in its envelope "mit spielerischer Langsamkeit," and the elusiveness of his possible motivation here is reflected in the variety of interpretations given to this phrase in the different voices: for $\mathrm{A} 2$ it was done in a "slow and dreamy fashion," for A3 he "toyed with it," for A4 it was done with "frivolous deliberation," for A6 it was simply "avec lenteur" and for A7 "lentamente," while A5 is clear that it was "avec une lenteur feinte," A8 talks of a "lentezza compiaciuta, quasi giocherellando," and A9 has it done "distraída y lánguidamente." The complexity of Georg's motivation here is a reflection of the complex processes that ostensibly impelled his alleged friend to leave home. This nameless friend had been "mit seinem Fortkommen zu Hause unzufrieden," as the German puts it in a deconstructive double entendre. "Fortkommen" is progress, but it is also "getting away," and "zu Hause," staying at home, is the familiar stumbling block to both. Two of the English voices (A3, A4) have him dissatisfied merely with his "progress," just as for A7 he is "scontento della sua esistenza in famiglia," and one of the French likewise (A6) has him "mécontent de piétiner au pays," dissatisfied with marking time, shuffling his feet. The other French voice (A5) has him "insatisfait de la situation qu' on lui avait faite," where progress has more overtly given way to stasis, and this is a situation that has ostensibly been thrust upon him, apparently through no fault or desire of his own. The passivity of his "situation" and the unattainability of any active "progress" leads in A2 to his being "dissatisfied with his prospects" (emphasis mine), as also in the Spanish A9, where he is "disconforme con las perspectivas que su patria le ofrecia." The "prospects" and "perspectivas" here are parodically reflected in the view or prospect observed by Georg from his window in the same paragraph, while the Spanish also not only alerts us through its use of "perspectivas" to the various game strategies that will be employed in the narrative but also stresses both the passivity of the friend - who is "offered" prospects - and the power to offer or withhold of the "patria," the land precisely of the father(s). The Italian A7 echoes the passivity but not the nom du pere of the Spanish: the friend was "insoddisfatto per quanto gli offriva il suo paese." 
This friend, Georg reflects in A1, "[hatte sich] vor Jahren schon nach Russland [...] förmlich geflüchtet." He "had actually run away" according to A2, "had quite simply decamped" according to A3, had "quite literally escaped" according to A4. But "literally" and "formlich" are both slippery words, and this is - once again - well caught by the difference between the two French voices, A6 with "litterralement enfui," A5 with "pour ainsi dire enfui." Everything that happens in a literary text is both "literal" and "so to speak," "pour ainsi dire." It is precisely the moment of indecision between the actual and the possible here and throughout Das Urteil that gives the text its compellingly provocative and enigmatic character. Das Urteil, in biographical terms, can clearly be read as about necessary decisions that were vital for Kafka at this point in his life: the decision whether to leave home or not, whether to stand up to his father once and for all or not, whether to risk marriage or not, and no doubt most important of all, whether any of these other decisions would endanger the one decision he had already and irrevocably taken, namely to go on writing at all costs. But Das Urteil is a literary text, and therefore its aboutness is more important than what it is about, its allusiveness is more important than its referentiality, its status as a literary, self-reflexive text is more important - for the particular theoretical game we are playing here at any rate - than its status as a real-world biographical text. Kafka, notoriously, confided to Max Brod that when he wrote the last sentence of Das Urteil - "In diesem Augenblick ging über die Brücke ein geradezu unendlicher Verkehr" (which the reader will find below in voices B1 to B9) - he was thinking of a powerful sexual ejaculation, "eine starke Ejakulation" (Neumann, 1981, p. 36). The serious-minded Brod, perennial Boswell to Kafka's Johnson, duly went away and wrote this down for posterity, and we need not concern ourselves here with the exact degree to which his scholarly leg was being pulled. As readers of a literary text, however, our leg is always being pulled, for the literary text always, by its very nature, says one thing and means another.

The friend in Russia, "[w]ie er erzählte, hatte [...] keine rechte Verbindung mit der dortigen Kolonie seiner Landsleute, aber auch fast keinen gesellschaftlichen Verkehr mit einheimischen Familien und richtete sich so für ein endgültiges Junggesellentum ein." In this shadow world of "Verkehr," where "Landsleute" are strangers and 
strangers are "einheimisch," the nameless friend has "fast keinen [...] Verkehr," no "intercourse," as all three English voices have it, no "relation sociale" for A5, no "rapport" for A6, no "rapporti" for A7 and A8, no "amistades" for A9, a friend in name who is nobody's friend in deed. When the "geradezu unendlicher Verkehr" passes over the bridge of the last paragraph, the same bridge we already know from the first paragraph but from which Georg has now let himself drop, there is (Max Brod notwithstanding) no "intercourse" in the English versions any more, only an "unending," "endless" "stream of traffic," "un trafic immense," as the French B5 puts it, "un traffico interminabile" for B7. As interpreters, critics, translators, readers in short, we are in a sense all part of that endless traffic over Kafka's bridge, "una interminable fila," as the Spanish has it, "un interminabile andirivieni" for the Italian B8, interminably going and coming, filing past, circling around the Kafkan text, in what B6 calls "une circulation littéralement folle."

One final key phrase with which to conclude our prelude to an endless reading of a tiny fragment of the Kafka system: the title. "Das Urteil" is rendered by all three English voices as "The Judg(e)ment" and by the French A5 likewise as "Le Jugement." But judgement is only one note, as we might put it, of the three-note chord that constitutes a judicial "Urteil," which contains first the process of forming a judgement, then the judicial utterance of the verdict reached, and finally the imposition of the punishment appropriate to the crime. The English title "The Judg(e)ment" and the French "Le Jugement" emphasize the first aspect of this process, the formation of a judicial opinion. The second aspect is emphasized by the second French title, "Le Verdict," the speaking of what is now judicial truth (verum dictare), and the third is underlined both by the Italian "La Condanna" and by the Spanish "La Condena," the condemnation, the imposition of the sentence. The final step in the judicial process exceeds the reach of the title in any of the languages examined here, namely the execution of the sentence, the death by drowning imposed by Georg's father. But, we might well ask ourselves, is that sentence ever carried out anyway? We see Georg, his own apparent executioner, let himself drop from the bridge, indeed. What we do not see is Georg ever reaching the water, much less drowning. Suspended between the inception and the completion of the act of self-execution, Georg finally leaves the reader where he has always been, faced with the necessity precisely of reading - forming 
his own judgement, passing his own sentence, executing his own decision.

For our first model of reading, the traditional, prestructuralist model, translation is essentially a reluctantly tolerated but sometimes necessary evil allowing readers to approach the work of authors otherwise linguistically inaccessible. The grateful reader's reaction is to ignore the translation as much as possible, indeed to treat it as nonexistent once he has been reassured by competent authorities that it is as faithful as possible to the original work he would preferably be reading directly rather than at one remove. For the second, the metatextual model of reading, drawing on structuralist concepts of textual interaction, translation emerges, in a dramatic paradigm shift, from this state of marginalized toleration to become the very template of all reading, all interpretation. For the first model, founded on the centrality of original, authorial authority, the reader reads in spite of a translation; for the second model, decentred, destabilized, and founded on the fragmentation of authority, translation is the only option there can ever be. For the third, the intertextual model of reading, drawing on poststructuralist conceptions of textuality, all the possible "translations" together constitute a parodic new, but endlessly inaccessible "original" - authority recentred (if only through the looking glass), but centre and circle coincide, and their circumference is incalculable.

Intriguing though such a concept might be in theoretical terms, our intertextual, macrotextual model might also seem at first sight to be little more than a self-sufficient academic game, a critical joke, of the kind in which contemporary literary theory increasingly abounds. 9 And, indeed, if taken exclusively as a model of translation, our third model obviously has extremely limited practical possibilities, since very few readers will be able to go in any meaningful way beyond a comparative consideration of translations in three or four of the more familiar foreign languages. Once again, however, the macrotextual model of translation is only one aspect of a more general model of reading, and for all that its paradoxical nature is abundantly clear once we attempt to employ it comprehensively, we all, in fact, use it quite practically and

9. For further discussion of the comic moment in contemporary literary theory, see O'Neill (1990), esp. pp. 54-65. 
quite frequently - indeed potentially always - in our reading of literary texts, even if we may do so both largely unconsciously and in a very much reduced application. "My" Odyssey, for example, is made up not of a single text immaculately preserved in my mind, but rather is the result of several different readings, at several different ages, in several different places, with several different degrees of concentration, of several different translations, combined with occasional study over two or three decades of selected passages in the original Greek, more or less eroded memories of lectures I have heard and books and articles I have read over many years on Homer, not to mention various halfunderstood popular treatments of the tale or parts of it read or seen since childhood in comic books, children's classics, the movies, and on $\mathrm{TV}^{10}$ What is true of my Odyssey is equally true of my Homer, my Dante, my Shakespeare, my Kafka - and my "Kafka" is not your "Kafka," nor yours mine.

Most of the time, of course, when I sit down as a critic to examine a literary text, I merely allow this macrotextual, intertextual, contextual information to function, more or less unconsciously, as a background of general knowledge to my more immediate endeavours. On a more conscious and more practical level, I essentially have to decide whether to operate according to the rules of either our first model or our second model, and if I should happen to be dealing with matters involving translation this will eventually bring me back, sooner or later, to the question of evaluation. As long as I adhere to the traditional model of reading, neither the traditional questions nor the traditional answers have changed, and fidelity to (assumed) authorial intention remains the unshakeable touchstone. Once I choose to operate by the rules of the second model, however, I am immediately faced with the question as to how one is supposed to evaluate a translation in this brave but unstable new world of floating authority.

The most productive answer here seems clearly to be that any evaluation will be based less usefully on traditional notions of fidelity to authorial norms than it will be on the same criteria we can most

10. For further discussion of this reduced variant of the intertextual model, see Lefevere (1982), pp. 148-149. 
usefully employ when judging the relative validity of any of competing sets of readings or interpretations. These are spelled out in exemplary fashion by Paul Armstrong in his PMLA article of 1983, and they are three in number. The first of them is the criterion of inclusiveness: any interpretation - and every translation is an interpretation - should capture a maximum of the information present in the text interpreted. To translate the title "Das Urteil" by "The Decision," for example, or "The Sentence," both of which options could be argued for to a certain point, would clearly fail to meet the criterion of inclusiveness, since neither captures nuances of meaning that, as we have seen, can be regarded as crucial to the narrative. The second criterion is that of persuasiveness: to translate the title as "The Opinion," for example, would not only fail to be inclusive but would also signally fail to exercise any power of persuasion that this was indeed the most appropriate solution. The third criterion is that of suggestiveness, and here the translation of the word "Kaufmann" by the French "négociant" rather than the English "merchant" or "businessman," as discussed above, provides an excellent example of how this criterion is brilliantly met in this instance by the French and met with only marginal adequacy by the English.

These are minimal cases, of course, dealing with single words or phrases only. The problem becomes massively more complicated when we attempt to evaluate a 500-page or a thousand-page translation. But this is as it has always been, and there is no getting away from it: every translation, like the text it translates, is made up of individual words individually chosen, and every single word is problematic. One man's meat will continue to remain - and should continue to remain - another man's poison, and our three criteria too, while providing us with a useful set of evaluative yardsticks, should certainly not be seen as offering any definitive and "scientific" solution. There is no such final solution, whether to the evaluation of translations or interpretations or the sort of theoretical models I have been discussing in this paper. Every reading, every interpretation, every translation, every theoretical model is a particular strategy, a particular game, played with more or less accomplishment, but always according to its own particular rules. Some games, some models, are better for some purposes, for some people, than others are. Our evaluative criteria will always depend in the end on where we stand - and why we find ourselves standing there 
rather than somewhere else. "Give me a place to stand, and I will move the world," Archimedes is reported - in translation, of course - to have said. Reformulated for the purposes of modern literary theory, the Archimedes principle retranslates today as "Give me a place to read, and I will rewrite the world - subject only to the equal right of all other readers to do likewise."

Queen's University

\section{Works cited}

\section{F. KAFKA: Primary Sources}

(1913). "Das Urteil." Neumann, pp. 7-19.

(1944). Le Jugement. Trans. Pierre Meylan. Porrentruy (Suisse), Éditions des Portes de France.

(1964). "Le Verdict." Trans. A. Vialatte. Euvres complètes de Franz Kafka, Éd. Marthe Robert. Paris, Gallimard, 4, pp. 4153.

(1964). Der Prozess (1925). Frankfurt/Main, Fischer Bücherei.

(1970). The Trial. Trans. Willa and Edwin Muir (1937). New York, Schocken.

(1970). "The Judgment." The Penal Colony: Stories and Short Pieces. Trans. Willa and Edwin Muir (1948). New York, Schocken, pp. 49-63.

(1977). "The Judgment." Trans. Malcolm Pasley. The Problem of The Judgment: Eleven Approaches to Kafka's Story. Ed. Angel Flores. New York, Gordian Press, pp. 1-12. 
(1978). La Condena. Trans. J.R. Wilcock (1967). Buenos Aires, Alianza Editorial.

(1980). "La Condanna." Trans. Rodolfo Paoli. Racconti. Ed. Ervino Pocar (1970). Milano, Mondadori, pp. 139-154.

(1981). "The Judgement." Franz Kafka: Stories 1904-1924. Trans. J.A. Underwood, London, Macdonald.

(1983). "La Condanna." Racconti. Trans. Giorgio Zampa (1957). Milano, Feltrinelli.

\section{Secondary Sources}

ARMSTRONG, Paul B. (1983). "The Conflict of Interpretations and the Limits of Pluralism." PMLA, 98, pp. 341-52.

BASSNETT-MCGUIRE, Susan (1980). Translation Studies. London and New York, Methuen, "New Accents."

EAGLETON, Terry (1983). Literary Theory: An Introduction. Minneapolis, University of Minnesota Press.

FRENZ, Horst $(1961,1973)$. "The Art of Translation." Comparative Literature: Method and Perspective. Ed. Newton P. Stallknecht and Horst Frenz. Carbondale, IL, Southern Illinois University Press, pp. 98-121.

KOLLER, Wemer (1984). Einführung in die Übersetzungswissenschaft. Uni-Taschenbuicher 819. 3rd edn. Heidelberg, Wiesbaden, Quelle \& Meyer.

LEFEVERE, André (1982). "Théorie littéraire et littérature traduite," Canadian Review of Comparative Literature, 9, pp. 137-156.

MACPHERSON, James (1847). The Poems of Ossian. Leipzig, Tauchnitz. 
NEUMANN, Gerhard (1981). Franz Kafka: Das Urteil. Text, Materialien, Kommentar. München, Hanser.

O'NEILL, Patrick (1990). The Comedy of Entropy: Humour, Narrative, Reading. Toronto, University of Toronto Press.

POPE, Alexander (1939-1969). Poems. Ed. John Butt. 11 vols. London, Methuen; New Haven, Yale University Press.

SINNEMANN, Barbara (1989). "Translating Kafka: The Case of Das Urteil." M.A. thesis. Queen's University, Canada.

\section{Appendix}

A1 Es war an einem Sonntagvormittag im schönsten Frühjahr. Georg Bendemann, ein junger Kaufmann [...] hatte gerade einen Brief an einen sich im Ausland befindenden Jugendfreund beendet [und] verschloss ihn in spielerischer Langsamkeit [...]. Er dachte darüber nach, wie dieser Freund, mit seinem Fortkommen zu Hause unzufrieden, vor Jahren schon nach Russland sich förmlich geflüchtet hatte [...]. Wie er erzahlte, hatte er keine rechte Verbindung mit der dortigen Kolonie seiner Landsleute, aber auch fast keinen gesellschaftlichen Verkehr mit einheimischen Familien und richtete sich so für ein endgültiges Junggesellentum ein. (Kafka, "Das Urteil," p. 8)

A2 It was a Sunday morning in the very height of spring. Georg Bendemann, a young merchant [...] had just finished a letter to an old friend of his who was now living abroad [and] had put it into its envelope in a slow and dreamy fashion [...]. He was thinking about his friend, who had actually run away to Russia some years before, being dissatisfied with his prospects at home [...]. By his own account he had no regular connection with the colony of his fellow countrymen out there and almost no social intercourse with Russian families, so that he was 
resigning himself to becoming a permanent bachelor. ("The Judgment," trans. Muir and Muir, pp. 49-50)

A3 It was a Sunday morning in the height of spring. Georg Bendemann, a young businessman [...] had just finished a letter to an old friend of his who was now living abroad [and] toyed with it for a while as he slowly sealed it [...]. He recalled how many years ago this friend of his, dissatisfied with his progress at home, had quite simply decamped to Russia [...]. By his own account he had no real contact with the colony of his fellow-countrymen out there, and indeed hardly any social intercourse with Russian families, so that he was resigning himself to becoming a permanent bachelor. ("The Judgment," trans. Pasley, p. 1)

A4 It was a Sunday morning at the height of spring. George Bendemann, a young businessman [...] had just completed a letter to a boyhood friend now living abroad [and] sealed it with frivolous deliberation [...]. He was thinking about how the friend, not content with his progress at home, had years before quite literally escaped to Russia [...]. By his own account he had no proper contact with his compatriots, who formed a colony in the city, and virtually no social intercourse with Russian families either, so that he was settling down to a life of permanent bachelordom. ("The Judgement," trans. Underwood, p. 45)

A5 C'était un dimanche matin, dans la beauté du printemps. Georges Bendemann, un jeune négociant [...] venait d'achever une lettre à un ami d'enfance résidant à l'étranger [et] l'avait fermée avec une lenteur feinte [...]. Ses pensées suivaient cet ami qui, insatisfait de la situation qu'on lui avait faite chez lui, s'était, quelques années auparavant, pour ainsi dire enfui en Russie [...]. D'après ses récits, non seulement il ne s'était guère lié avec ses compatriotes, mais il n'avait également aucune relation sociale avec les familles indigènes et, de cette façon, se vouait à un célibat définitif. ("Le Jugement," trans. Meylan, pp. 9-13) 
A6 C'était un matin de dimanche, par une année qui débutait splendidement. Georges Bendemann, un jeune négociant [...] venait de terminer une lettre à un ami de jeunesse qui habitait l'étranger [et] commença par la fermer avec lenteur [...]. Il réfléchissait au destin de cet ami qui, mécontent de piétiner au pays, s'était littéralement enfui en Russie [...]. Il n'avait, a ce qu'il disait, aucune relation réelle avec la colonie de ses compatriotes, et presque aucun rapport non plus avec la société indigène; il semblait donc se préparer un célibat définitif. ("Le Verdict," trans. Vialatte, pp. 41-42)

A7 Era una domenica mattina di primavera, faceva un tempo splendido. Il giovane commerciante Giorgio Bendemann [...] aveva appena finito una lettera per un amico di gioventú che si trovava all'estero, la chiuse lentamente [...]. Pensava all'amico che, insoddisfatto per quanto gli offriva il suo paese, parecchi anni avanti era letteralmente fuggito in Russia [...]. Raccontava di non avere stretto rapporti con la colonia dei suoi compatrioti, mentre ben scarse erano le sue relazioni con la gente del posto; era ormai rassegnato a rimanere celibe. ("La Condanria," trans. Zampa, p. 99)

A8 Era una mattinata domenicale nel momento più bello della primavera. Giorgio Bendemann, un giovane commerciante [...] aveva finito allora una lettera ad un amico d'infanzia che viveva all'estero; la chiuse con una lentezza compiaciuta, quasi giocherellando [...]. Meditava sul fatto che questo amico, scontento della sua esistenza in famiglia, già da anni s'era come rifugiato in Russia [...]. Secondo quel che raccontava non era in rapporti attivi colla colonia dei suoi connazionali, né aveva stretto quasi nessuna relazione d'amicizia con famiglie del luogo e s'avviava così a restar definitivamente scapolo. ("La Condanna," trans. Paoli, p. 141)

A9 Era una mañana de domingo, en plena primavera. Georg Bendemann, joven comerciante [...] acababa de escribir una carta a un amigo de infancia que se encontraba en el extranjero [y] la cerró distraída y lánguidamente [...]. Pensaba en su amigo, que algunos años antes, disconforme con las perspec- 
tivas que su patria le ofrecía, se había ido a Rusia [...]. Según él decía, no tenía mayores relaciones con la colonia de compatriotas en aquella ciudad ni tampoco amistades entre las familias del lugar, de modo que su destino parecía ser una definitiva soltería. ("La Condena," trans. Wilcock, pp. 9-10)

B1 In diesem Augenblick ging über die Brücke ein geradezu unendlicher Verkehr. ("Das Urteil," p. 19)

B2 At this moment an unending stream of traffic was just going over the bridge. ("The Judgment," trans. Muir and Muir, p. 63)

B3 At that moment the traffic was passing over the bridge in a positively unending stream. ("The Judgment," trans. Pasley, p. 12)

B4 Crossing the bridge at that moment was a simply endless stream of traffic. ("The Judgement," trans. Underwood, p. 56)

B5 En cet instant, il $\mathrm{y}$ avait justement sur le pont un trafic immense. ("Le Jugement," trans. Meylan, p. 63)

B6 À ce moment, il y avait sur le pont une circulation littéralement folle. ("Le Verdict," trans. Vialatte, p. 53)

B7 In quel momento il ponte era percorso da un traffico interminabile. ("La Condanna," trans. Zampa, p. 113)

B8 In quel momento sul ponte c'era un interminabile andirivieni di persone e di veicoli. ("La Condanna," trans. Paoli, p. 154)

B9 En ese momento una interminable fila de vehículos pasaba por el puente. ("La Condena," trans. Wilcock, p. 21) 